\title{
The importance of the non-protein components of the diet in the plasma cholesterol response of rabbits to casein
}

\author{
By E. C. AlLOTTA*, S. SAMMAN AND D. C. K. ROBERTS $\dagger$ \\ Human Nutrition Unit, Department of Biochemistry, University of Sydney, \\ NSW 2006, Australia \\ (Received 22 May 1984 - Accepted 10 January 1985)
}

\begin{abstract}
1. To characterize the hypercholesterolaemic effect of casein further, four groups of young male rabbits in two separate experiments were placed on cholesterol-free semi-purified diets for 12 weeks. The diets were similar in composition, with either casein or soya-bean-protein isolate providing the protein source $(250 \mathrm{~g} / \mathrm{kg})$. In two of these diets the salt mix was reduced by $45 \%$ (normally $40 \mathrm{~g} / \mathrm{kg}$ ) and replaced by potassium bicarbonate.

2. Growth was unaffected by these alterations in dietary salts except for one group given the soyabean-reduced-salts diet.

3. The mean concentrations of plasma cholesterol were significantly higher in all casein-fed groups as compared with their soya-bean-fed counterparts but the response was much greater in those given the casein-reduced-salts diet.

4. Contrary to expectations, analysis of the diets showed the zinc and copper concentrations of the casein diets to be less than those of the soya-bean diets. This was due to the greater concentrations of $\mathrm{Cu}$ (threefold) and $\mathrm{Zn}$ (twofold) in the soya-bean-protein isolate compared with casein.

5. The mean concentration of $\mathrm{Zn}$ in fur was significantly decreased in casein-fed rabbits and these animals also excreted less $\mathrm{Zn}$ but more $\mathrm{Cu}$ in their urine than those given the casein-reduced-salts diet.

6. The rabbits given the casein diet with the least salt mix showed the greatest degree of hypercholesterolaemia, suggesting an interaction between trace elements and the casein effect.
\end{abstract}

It has been clearly shown that dietary protein can influence cholesterol metabolism in rabbits (Carroll \& Hamilton, 1975; Hermus, 1975; Kritchevsky, 1979). Hypercholesterolaemia and atherosclerosis can be evoked by feeding cholesterol-free, semi-purified diets containing casein as the protein component (Hermus, 1975; Roberts, 1981; Terpstra et al. 1982) and the observed hypercholesterolaemia has been attributed to the protein source (Huff et al. 1977; Huff \& Carroll, 1980; Terpstra \& Sanchez-Muniz, 1981). Huff \& Carroll (1980) showed that the amino acid composition of dietary protein plays an important role in regulating serum cholesterol levels. Rabbits given semi-purified diets containing an amino acid mixture resembling the composition of casein also develop hypercholesterolaemia but not to the same extent as those given the intact protein. Studies by Terpstra \& Sanchez-Muniz (1981) have confirmed the differential effect of dietary casein and soya-bean protein on serum cholesterol levels in rabbits, and have shown that soya-bean protein is able to reduce casein-induced hypercholesterolaemia.

However, other dietary components in combination with casein have been shown to influence plasma cholesterol levels in rabbits. The type and amount of fat (Lacombe \& Nibbelink, 1980; Beynen \& West, 1981) and carbohydrate (Carroll \& Hamilton, 1975) modify the hypercholesterolaemic response of rabbits to casein (Wigand, 1959; Carroll, 1971). Polyunsaturated fatty acids have been shown to decrease the hypercholesterolaemic effect of casein (Carroll, 1971) and dietary cholesterol markedly elevates plasma cholesterol levels in casein-fed rabbits (Lacombe \& Nibbelink, 1980).

Casein-containing diets not only influence cholesterol metabolism in rabbits but also reduce the animals' growth rate relative to chow-fed rabbits (Hermus, 1975). The effect that this may have on plasma cholesterol levels is unknown but it has been reported (Beynen \&

\footnotetext{
* Present address: Lipid Research Clinic, Department of Medicine, St Vincent's Hospital, Darlinghurst, NSW 2010, Australia.

+ For reprints.
} 
Table 1. Composition $(\mathrm{g} / \mathrm{kg})$ of the semi-purified diets

\begin{tabular}{lcccccc}
\hline \hline & Casein* & Casein $\dagger$ & $\begin{array}{c}\text { Casein- } \\
\text { reduced } \\
\text { salts* }\end{array}$ & $\begin{array}{c}\text { Casein- } \\
\text { reduced } \\
\text { salts } \dagger\end{array}$ & $\begin{array}{c}\text { Soya } \\
\text { bean }\end{array}$ & $\begin{array}{c}\text { Soya bean- } \\
\text { reduced } \\
\text { salts }\end{array}$ \\
\hline $\begin{array}{l}\text { Diet... } \\
\text { Casein } \ddagger\end{array}$ & 270 & 292 & 270 & 292 & - & - \\
$\begin{array}{l}\text { Soya-bean-protein } \\
\text { isolate }\end{array}$ & - & - & - & - & 270 & 270 \\
$\begin{array}{l}\text { Dextrose } \\
\text { Cellufiour }\end{array}$ & 600 & 600 & 600 & 600 & 600 & 600 \\
$\begin{array}{l}\text { Molasses (500 ml } / 1) \\
\text { Maize oil (ml) }\end{array}$ & 50 & 50 & 50 & 50 & 50 & 50 \\
$\begin{array}{l}\text { Salt mix } \\
\text { Potassium } \\
\text { bicarbonate }\end{array}$ & 20 & 10 & 20 & 20 & 20 & 20 \\
\hline \hline
\end{tabular}

Soya-bean-protein isolate was obtained from Procol Products Pty Ltd, Sydney (Pro-col 90 Product of USA). Dextrose monohydrate was obtained from Fielders Starches, Sydney.

Salt mix was obtained from ICN Pharmaceuticals Inc., Life Sciences Group, Cleveland, Ohio, USA or mixed as required, the composition being $(\mathrm{g} / \mathrm{kg}): \mathrm{NaCl} 193 \cdot 7, \mathrm{~K}_{2} \mathrm{HPO}_{4} 324 \cdot 5, \mathrm{CaHPO}_{4} \cdot 2 \mathrm{H}_{2} \mathrm{O} 62 \cdot 4, \mathrm{MgSO}_{4} \cdot 7 \mathrm{H}_{2} \mathrm{O} 102 \cdot 7$, $\mathrm{CaCO}_{3} 301 \cdot 9, \mathrm{Fe}$ citrate $13 \cdot 1, \mathrm{Kl} 0 \cdot 81, \mathrm{MnSO}_{4} \cdot 4 \mathrm{H}_{2} \mathrm{O} 0 \cdot 35, \mathrm{ZnCl}_{2} 0 \cdot 25, \mathrm{CuSO}_{4} .5 \mathrm{H}_{2} \mathrm{O} 0 \cdot 3$.

Vitamins were obtained from the Sigma Chemical Co., St Louis, MO, USA.

Water-soluble vitamins $(\mathrm{g} / 1)$ : thiamin hydrochloride 0.05 , pyridoxine monohydrochloride 0.05 , D-biotin 0.02 , myo-inositol 10 , riboflavin 1 , nicotinic acid 5 , calcium pantothenoate 5.9 , folic acid 0.05 , choline chloride 100 ; dissolved in $50 \%(\mathrm{v} / \mathrm{v})$ ethanol and $15 \mathrm{ml}$ added $/ \mathrm{kg}$ diet.

Fat-soluble vitamins $(\mathrm{g} / 1$ maize oil): trans-retinol palmitate 10, DL- $\alpha$-tocopherol acetate 11, menadione 3, dissolved in maize oil (to provide a source of essential fatty acids) and $10 \mathrm{ml}$ added $/ \mathrm{kg}$ diet.

* Casein obtained from ICN Pharmaceuticals Inc. (vitamin-free, purified, high nitrogen) $(950 \mathrm{~g}$ protein $/ \mathrm{kg}$, proximate composition).

$\dagger$ Casein obtained from the Colac Dairying Co. Ltd, Victoria (colachydrochloric casein; edible extra grade) $(920 \mathrm{~g}$ protein $/ \mathrm{kg}$, proximate composition, and $15 \mathrm{~g}$ fat $/ \mathrm{kg})$. The volume of maize oil was adjusted to account for the fat content of the casein product.

$\ddagger$ Casein and soya-bean protein isolate were added in these amounts to provide $250 \mathrm{~g}$ protein $/ \mathrm{kg} \mathrm{diet}$.

van Wanrooy-Stroeken, 1981) that weight gain can be improved by the addition of potassium bicarbonate to casein-containing diets. This addition would, however, alter the mineral balance of the diet which may also influence cholesterol metabolism.

As part of a study to explore casein-induced hypercholesterolaemia further, potassium bicarbonate was incorporated into the rabbits' diets. Since this involved altering the mineral mix of the diet and because of the importance of zinc and copper in cholesterol metabolism (Klevay, 1973; Allen \& Klevay, 1978; Harvey \& Allen, 1981; Lau \& Klevay, 1982), we assessed the $\mathrm{Zn}$ and $\mathrm{Cu}$ concentrations of the diets. Contrary to the view that casein and soya-bean diets are similar in all respects except for the protein, the results reported here show that the casein diets contained significantly less $\mathrm{Cu}$ and $\mathrm{Zn}$ than the soya-bean diets and that this difference may contribute significantly to the hypercholesterolaemic effect of casein.

\section{MATERIALS AND METHODS \\ Animals and diets}

Young adult male rabbits, Castle Hill Laboratory White strain (University of Sydney, Castle Hill Animal House, NSW), about 6 weeks old and weighing between 1.5 and $2.0 \mathrm{~kg}$, were housed individually in wire cages with mesh bottoms in an air-conditioned room with 
controlled temperature, $23-24^{\circ}$, and artificial lighting ( $12 \mathrm{~h}$ light-12 h dark cycle). On arrival the rabbits were maintained on rabbit chow (Purina rabbit and guinea-pig pellets, Allied Feeds, Rhodes, NSW) for up to 2 weeks. Two studies were carried out. Because of the unusual results obtained in the first, a second experiment was undertaken to obtain more information about the $\mathrm{Cu}$ and $\mathrm{Zn}$ status of the animals. In both experiments, animals were weight paired into four groups. Each group was then transferred to a low-fat, cholesterol-free, semi-purified pelleted diet, containing either casein or soya-bean-protein isolate as the protein source. In two of the diets $45 \%$ of the salt mix (Table 1) were substituted by potassium bicarbonate such that this salt provided $18 \mathrm{~g} / \mathrm{kg}$ diet (the composition of the semi-purified diets is shown in Table 1). Numbers were initially equal in the groups of Expt 1 ( $n 7$ for the standard salt diets, $n 6$ for the reduced-salts diet). However, two deaths in the soya-bean group, both unrelated to the treatment (one respiratory infection and one middle-ear infection), reduced numbers to five in that group. Food was restricted to $900 \mathrm{~g} /$ week per animal for all dietary groups. Deionized water was provided ad lib. and the rabbits were weighed weekly.

\section{Sampling of tissues and chemical analyses}

Plasma cholesterol was assayed fortnightly. Non-fasting animals were bled from the marginal ear vein into centrifuge tubes containing EDTA $(0.4 \mathrm{mM}, \mathrm{pH} 7.4)$ and plasma separated by centrifugation $(1170 \mathrm{~g}, 5 \mathrm{~min})$. In the first experiment, total plasma cholesterol was extracted and saponified as described by Mann (1961) and analysed by the method of Zlatkis \& Zak (1969). In the second experiment, plasma cholesterol was analysed by an automated enzymic method (Monotest Cholesterol, CHOD-PAP method; Boehringer, Mannheim, W. Germany).

At the end of the second experiment, animals were killed by anaesthetic overdose (Anathal; VR Laboratories Pty Ltd, Thornleigh, NSW). Fur was collected from the lumbar region and small samples $(2-5 \mathrm{~g})$ of liver removed for subsequent analysis.

\section{$\mathrm{Zn}$ and $\mathrm{Cu}$ analyses of diets and tissues}

Triplicate samples (1-5 g) of the diet and dietary components were ashed overnight in a - muffle furnace $\left(475^{\circ}\right)$, the residue dissolved in $25 \mathrm{ml}$ hydrochloric acid $(3 \mathrm{M})$ and the $\mathrm{Zn}$ and Cu concentrations measured using an atomic absorption spectrophotometer (Varian Model AA-575) with appropriate standards. Samples of urine and plasma were diluted tenfold and the concentrations of $\mathrm{Cu}$ and $\mathrm{Zn}$ measured using the method of Meret \& Henkin (1971). Fur, washed using the method of Mckenzie (1978), and freeze-dried liver were treated in the same manner as the diets.

\section{RESULTS}

\section{Weight gain and plasma cholesterol}

Mean gain in weight was similar between dietary groups except for one group (Expt 1) consuming the soya-bean-reduced-salts diet in which mean gain in weight was significantly greater than for all other groups (Table 2). Considerable variation in mean concentration of plasma total cholesterol was seen over the 12-week period in all groups (Table 3). To normalize the variance between groups, the values were expressed as the change in cholesterol concentration from the initial value. Those animals given the casein diets either showed no change or a slight increase in mean concentration of plasma cholesterol by 12 weeks, whereas those given the soya-bean diet decreased slightly and those given the soya-bean-reduced-salts diet decreased somewhat more from their initial levels. Analysis of variance of the values after 12 weeks on the diets indicated that there was a significant effect of protein on plasma cholesterol response but not of salt alone (Table 3). There was, 
Table 2. Effect of diet composition $\dagger$ on mean body-weights $(\mathrm{kg})$ of rabbits

(Mean values with their standard errors)

\begin{tabular}{|c|c|c|c|c|c|c|c|c|c|c|}
\hline \multirow[b]{3}{*}{ Diet } & \multirow{3}{*}{$\begin{array}{l}\text { Expt } \\
\text { no. }\end{array}$} & \multirow[b]{3}{*}{$n$} & \multicolumn{6}{|c|}{ Period on diet (weeks) } & \multirow{2}{*}{\multicolumn{2}{|c|}{$\begin{array}{c}\text { Mean wt gain } \\
(\mathrm{g} / \mathrm{d})\end{array}$}} \\
\hline & & & \multicolumn{2}{|c|}{0} & \multicolumn{2}{|c|}{6} & \multicolumn{2}{|c|}{12} & & \\
\hline & & & Mean & SE & Mean & SE & Mean & SE & Mean & SE \\
\hline Casein & $\begin{array}{l}1 \\
2\end{array}$ & $\begin{array}{l}7 \\
6\end{array}$ & $\begin{array}{l}2 \cdot 01 \\
2 \cdot 09\end{array}$ & $\begin{array}{l}0.05 \\
0.10\end{array}$ & $\begin{array}{l}2 \cdot 37 \\
2 \cdot 49\end{array}$ & $\begin{array}{l}0.04 \\
0.09\end{array}$ & $\begin{array}{l}2 \cdot 48 \\
2 \cdot 48\end{array}$ & $\begin{array}{l}0.09 \\
0.14\end{array}$ & $\begin{array}{l}4.89 \\
4.73\end{array}$ & $\begin{array}{l}0 \cdot 88 \\
0 \cdot 38\end{array}$ \\
\hline Soya-bean & $\begin{array}{l}1 \\
2\end{array}$ & $\begin{array}{l}5 \\
6\end{array}$ & $\begin{array}{l}2 \cdot 08 \\
2 \cdot 00\end{array}$ & $\begin{array}{l}0.04 \\
0.09\end{array}$ & $\begin{array}{l}2 \cdot 41 \\
2 \cdot 32\end{array}$ & $\begin{array}{l}0.09 \\
0.09\end{array}$ & $\begin{array}{l}2 \cdot 60 \\
2 \cdot 50\end{array}$ & $\begin{array}{l}0.14 \\
0 \cdot 10\end{array}$ & $\begin{array}{l}5.91 \\
5.92\end{array}$ & $\begin{array}{l}1.52 \\
0.08\end{array}$ \\
\hline $\begin{array}{l}\text { Casein- } \\
\text { reduced-salts }\end{array}$ & $\begin{array}{l}1 \\
2\end{array}$ & $\begin{array}{l}6 \\
6\end{array}$ & $\begin{array}{l}1.86 \\
1.60\end{array}$ & $\begin{array}{l}0 \cdot 10 \\
0 \cdot 06\end{array}$ & $\begin{array}{l}2 \cdot 21 \\
2 \cdot 20\end{array}$ & $\begin{array}{l}0.05 \\
0.05\end{array}$ & $\begin{array}{l}2 \cdot 31 \\
2 \cdot 18\end{array}$ & $\begin{array}{l}0.11 \\
0.15\end{array}$ & $\begin{array}{l}5.59 \\
6.90\end{array}$ & $\begin{array}{l}1 \cdot 24 \\
0.05\end{array}$ \\
\hline $\begin{array}{l}\text { Soya-bean- } \\
\text { reduced-salts }\end{array}$ & $\begin{array}{l}1 \\
2\end{array}$ & $\begin{array}{l}6 \\
6\end{array}$ & $\begin{array}{l}1 \cdot 82 \\
1.57\end{array}$ & $\begin{array}{l}0 \cdot 10 \\
0 \cdot 04\end{array}$ & $\begin{array}{l}2 \cdot 37 \\
1 \cdot 78\end{array}$ & $\begin{array}{l}0.07 \\
0.06\end{array}$ & $\begin{array}{l}2 \cdot 64 \\
2.09\end{array}$ & $\begin{array}{l}0.10 \\
0.08\end{array}$ & $\begin{array}{l}0.58^{*} \\
6 \cdot 21\end{array}$ & $\begin{array}{l}1.25 \\
0.56\end{array}$ \\
\hline
\end{tabular}

Mean value was significantly different from that for all other groups (Students' $t$ test): ${ }^{*} P<0.05$.

$\dagger$ For details, see Table 1 and p. 89.

however, a significant effect of the protein-salt interaction on the plasma cholesterol response. This is clear from the results where it can be seen that in both experiments casein, in the presence of reduced salts, produced a greater response than casein alone and that soya-bean in the presence of reduced salts produced a larger decrease than soya-bean alone.

\section{$\mathrm{Zn}$ and $\mathrm{Cu}$ analyses of diets and tissues}

The $\mathrm{Cu}$ and $\mathrm{Zn}$ concentrations of the soya-bean-containing diets were higher than those of the casein diets (Table 4), and the reduced-salts diets contained correspondingly less of these minerals than the standard-salts diets. The difference in the $\mathrm{Zn}$ and $\mathrm{Cu}$ contents of the soya-bean and casein diets was due to the differing amounts in the protein isolates, with the soya-bean-protein isolate containing about twice the concentration of $\mathrm{Zn}$ and three times that of $\mathrm{Cu}$ compared with casein (Table 5).

The mean concentrations of $\mathrm{Zn}$ and $\mathrm{Cu}$ in liver did not vary among the dietary groups, nor did the mean concentration of plasma $\mathrm{Zn}$ (Table 6). However, the mean concentration of $\mathrm{Zn}$ in fur was significantly decreased in casein-fed animals when compared with soya-bean-fed animals and was further decreased in those groups given the reduced-salts diets.

When urine volume was taken into account, $\mathrm{Zn}$ excretion was five times higher in those given the reduced-salts diets compared with the control groups and $\mathrm{Cu}$ excretion was lower in the group given casein reduced-salts.

\section{DISCUSSION}

These results suggest that mineral differences together with the type of dietary protein have a significant effect on plasma cholesterol levels in rabbits and that growth rate was unimportant in this response.

West et al. (1982) have suggested that differences in growth rates between rabbits given diets containing casein and soya-bean-protein may contribute to the observed differences in plasma cholesterol levels. The similar growth rates between the casein dietary groups and the significant differences in plasma cholesterol responses would seem to exclude any possibility 
Table 3. Effect of diet composition $\dagger$ on plasma cholesterol concentration $(\mathrm{mg} / \mathrm{l})$ of rabbits

(Mean value with $95 \%$ confidence intervals. Results are expressed as absolute values for week 0 and change from week 0 at week 6 and week 12)

\begin{tabular}{|c|c|c|c|c|c|c|c|}
\hline \multirow[b]{3}{*}{ Diet } & \multirow[b]{3}{*}{$n$} & \multicolumn{6}{|c|}{ Period on diet (weeks) } \\
\hline & & \multicolumn{2}{|r|}{0} & \multicolumn{2}{|r|}{6} & \multicolumn{2}{|c|}{12} \\
\hline & & Mean & $\begin{array}{l}95 \% \\
\text { confidence } \\
\text { interval }\end{array}$ & Mean & $\begin{array}{c}95 \% \\
\text { confidence } \\
\text { interval }\end{array}$ & Mean & $\begin{array}{c}95 \% \\
\text { confidence } \\
\text { interval }\end{array}$ \\
\hline \multicolumn{8}{|l|}{ Expt 1} \\
\hline Casein & 7 & 535 & 150 & 139 & 580 & 11 & 350 \\
\hline Soya-bean & 5 & 358 & 180 & -64 & 150 & -156 & 210 \\
\hline $\begin{array}{l}\text { Casein- } \\
\text { reduced-salts }\end{array}$ & 6 & 596 & 270 & 645 & 760 & 607 & 200 \\
\hline $\begin{array}{l}\text { Soya-bean- } \\
\text { reduced-salts }\end{array}$ & 6 & 634 & 250 & -393 & 210 & -320 & 70 \\
\hline \multicolumn{8}{|l|}{ Expt 2} \\
\hline Casein & 6 & 489 & 550 & 473 & 450 & 535 & 750 \\
\hline Soya-bean & 6 & 547 & 380 & -56 & 220 & -151 & 210 \\
\hline $\begin{array}{l}\text { Casein-- } \\
\text { reduced-salts }\end{array}$ & 6 & 993 & 460 & 321 & 770 & 1895 & 990 \\
\hline \multirow[t]{2}{*}{$\begin{array}{l}\text { Soya-bean- } \\
\text { reduced-salts }\end{array}$} & 6 & 1096 & 230 & -399 & 280 & -548 & 400 \\
\hline & \multicolumn{5}{|c|}{ Analysis of variance of response at week 12} & & \\
\hline \multicolumn{2}{|l|}{ Source of variation } & \multicolumn{2}{|c|}{ Sum of squares } & df & Mean square & \multicolumn{2}{|c|}{ Variance ratio } \\
\hline \multicolumn{8}{|l|}{ Expt $1 \ddagger$} \\
\hline Protein & & & 18050 & 1 & 18050 & \multicolumn{2}{|c|}{$14^{* * *}$} \\
\hline Salt & & & 3651 & 1 & 3651 & \multicolumn{2}{|c|}{ NS } \\
\hline Protein-salt & & & 8529 & 1 & 8529 & \multirow{2}{*}{\multicolumn{2}{|c|}{$6 \cdot 6^{*}$}} \\
\hline Within subclasses & & & 25863 & 20 & 1293 & & \\
\hline \multicolumn{8}{|l|}{ Expt 2} \\
\hline Protein & & & 46808 & 1 & 146808 & \multicolumn{2}{|c|}{$35^{* *}$} \\
\hline Salt & & & 13932 & 1 & 13932 & \multicolumn{2}{|c|}{ NS } \\
\hline Protein-salt & & & 46323 & 1 & 46323 & \multicolumn{2}{|c|}{$10 \cdot 9 * *$} \\
\hline Within subclasses & & & 84502 & 20 & 4225 & & \\
\hline
\end{tabular}

NS, not significant.

$* P<0.05,{ }^{* *} P<0.01$.

+ For details, see Table 1 and p. 89.

$\ddagger$ Adjusted for unéqual sample size (Snedecor \& Cochran, 1968).

Table 4. Total zinc and copper contents $(\mathrm{mg} / \mathrm{kg})$ of the diets ${ }^{*}$ given to rabbits

(Results are expressed as the mean of triplicate analyses from two batches of each diet)

\begin{tabular}{|c|c|c|c|c|c|}
\hline Diet... & Expt & Casein & $\begin{array}{l}\text { Soya } \\
\text { bean }\end{array}$ & $\begin{array}{l}\text { Casein- } \\
\text { reduced-salts }\end{array}$ & $\begin{array}{l}\text { Soya-bean- } \\
\text { reduced-salts }\end{array}$ \\
\hline \multirow[t]{2}{*}{$\mathrm{Zn}$} & 1 & $11 \cdot 63$ & $25 \cdot 34$ & $11 \cdot 29$ & $24 \cdot 80$ \\
\hline & 2 & 13.59 & $20 \cdot 73$ & 11.88 & $20 \cdot 78$ \\
\hline \multirow[t]{2}{*}{$\mathrm{Cu}$} & 1 & 3.97 & 5.73 & $2 \cdot 55$ & $5 \cdot 20$ \\
\hline & 2 & 3.69 & 4.63 & $3 \cdot 00$ & $4 \cdot 35$ \\
\hline
\end{tabular}

* For details, see Table 1 and p. 89. 
Table 5. Total zinc and copper contents $(\mathrm{mg} / \mathrm{kg})$ of the dietary components*

(Results are expressed as the mean of triplicate analyses)

\begin{tabular}{lcccrr}
\hline \hline & Salt mix & Molasses & Celluflour & Casein & \multicolumn{2}{c}{$\begin{array}{c}\text { Soya-bean- } \\
\text { protein }\end{array}$} \\
\hline $\mathrm{Zn}$ & 58.92 & 9.27 & 1.68 & 27.42 & 62.29 \\
$\mathrm{Cu}$ & 83.79 & 3.32 & 0.59 & 1.58 & 5.22 \\
\hline
\end{tabular}

* For details, see Table 1.

Table 6. Expt 2. Effect of diet composition§ on the total zinc and copper contents of rabbit tissues

(Mean values with their standard errors)

\begin{tabular}{|c|c|c|c|c|c|c|c|c|}
\hline \multirow[b]{2}{*}{ Diet } & \multicolumn{2}{|c|}{$\begin{array}{l}\text { Plasma } \\
(\mu \mathrm{g} / \mathrm{ml})\end{array}$} & \multicolumn{2}{|c|}{$\begin{array}{l}\text { Furr } \\
(\mu \mathrm{g} / \mathrm{g})\end{array}$} & \multicolumn{2}{|c|}{$\begin{array}{c}\text { Liver } \\
(\mu \mathrm{g} / \mathrm{g} \text { wet wt })\end{array}$} & \multicolumn{2}{|c|}{$\begin{array}{c}\text { Urine } \\
(\mu \mathrm{g} / 24 \mathrm{~h})\end{array}$} \\
\hline & Mean & SE & Mean & $\mathrm{SE}$ & Mean & $\mathrm{SE}$ & Mean & SE \\
\hline \multicolumn{9}{|c|}{ Zinc } \\
\hline Casein & 0.9 & $0 \cdot 10$ & 197 & $1 \cdot 8$ & 38 & $4 \cdot 5$ & $13 \cdot 2^{* *}$ & 0.89 \\
\hline Soya-bean & $1 \cdot 0$ & 0.09 & $241 \dagger$ & 3.9 & 31 & $5 \cdot 3$ & $17 \cdot 0^{* *}$ & 0.61 \\
\hline $\begin{array}{l}\text { Casein- } \\
\text { reduced-salts }\end{array}$ & 0.8 & 0.09 & 116 & $30 \cdot 8$ & 31 & 0.5 & $82 \cdot 5$ & $2 \cdot 62$ \\
\hline $\begin{array}{l}\text { Soya-bean- } \\
\text { reduced-salts }\end{array}$ & 0.8 & $0 \cdot 10$ & 96 & $7 \cdot 1$ & 33 & $1 \cdot 7$ & $77 \cdot 2$ & 3.63 \\
\hline \multicolumn{9}{|c|}{ Copper } \\
\hline Casein & 0.8 & $0 \cdot 11$ & 10 & 0.9 & $4 \cdot 5$ & 0.5 & $53.9 \ddagger$ & $4 \cdot 4$ \\
\hline Soya-bean & 0.9 & 0.06 & 11 & $1 \cdot 1$ & $3 \cdot 1$ & 0.9 & $35 \cdot 7^{\circ}$ & 1.8 \\
\hline $\begin{array}{l}\text { Casein- } \\
\text { reduced-salts }\end{array}$ & 1.4 & 0.14 & 16 & $2 \cdot 6$ & $4 \cdot 4$ & 0.3 & $36 \cdot 3$ & $1 \cdot 16$ \\
\hline $\begin{array}{l}\text { Soya-bean- } \\
\text { reduced-salts }\end{array}$ & 0.6 & 0.06 & 22 & $2 \cdot 4$ & $4 \cdot 3$ & 0.6 & $46 \cdot 8$ & $1 \cdot 5$ \\
\hline
\end{tabular}

Mean value was significantly lower than that for reduced salts, dietary counterpart (Student's $t$ test): ${ }^{* *} P<0 \cdot 01$.

Mean value was significantly different from that for other dietary groups within the same tissue (Student's $t$ test): $\dagger P<0.05$.

Mean value was significantly different from that for corresponding reduced-salts diet (Student's $t$ test): $\ddagger P<0.01$.

of a link between weight gain and plasma cholesterol in the present study. The substitution of a portion of the salt mix in the diets by potassium bicarbonate did not result in any apparent deficiency of essential elements required for adequate growth and did not affect the growth rate of the casein-fed rabbits. However the substitution of potassium bicarbonate in the soya-bean-containing diet significantly improved growth rate in one group (Expt 1) but not the other (Expt 2).

Variations were seen in the degree of induced hypercholesterolaemia amongst the animals given the different diets (Table 3). Rabbits developed hypercholesterolaemia when given the casein-reduced-salts diet, while rabbits given the casein diet maintained normal or only slightly elevated levels of plasma cholesterol, which were slightly lowered in those animals 
given either of the soya-bean-containing diets. The lack of a marked hypercholesterolaemic response in the casein-fed animals and the enhanced hypercholesterolaemic response seen when the salt mix was replaced by potassium bicarbonate suggests that potassium bicarbonate may have an independent effect on plasma cholesterol. Beynen \& van Wanrooy-Stroeken (1981) have suggested that dietary bicarbonate may serve as a buffer, counteracting the observed aciduria induced by dietary casein and perhaps correcting a potential disturbance of acid-base equilibrium which in some way influences plasma cholesterol homeostasis. This effect, if any, was not observed in those animals given the soya-bean-reduced-salts diet compared with those given the soya-bean diet.

A second possibility concerning the effect of potassium bicarbonate substitution on plasma cholesterol levels relates to the altered mineral balance of the semi-purified diets. Klevay (1973) initially proposed that the ratio, zinc:copper can influence the degree of dietaryinduced hypercholesterolaemia in rats. Surprisingly, the casein-containing diets used in the present study had lower concentrations of $\mathrm{Cu}$ and $\mathrm{Zn}$ than the soya-bean-containing diets (Table 4). Analysis of the dietary protein component of the diets showed the amount of $\mathrm{Cu}$ and $\mathrm{Zn}$ to be lower in casein than in soya-bean-protein isolate. Thus the reduction of total salt mix resulted in at least a gradation in the $\mathrm{Cu}$ and $\mathrm{Zn}$ contents of the diets, with soya-bean > soya-bean-reduced-salts > casein > casein-reduced-salts. It is evident, therefore, that the reduced-salts diet with the least $\mathrm{Cu}$ and $\mathrm{Zn}$ was the most hypercholesterolaemic (Table 3), and that an apparent inverse relation exists between the plasma cholesterol level at 12 weeks and the $\mathrm{Cu}$ and $\mathrm{Zn}$ concentrations of the diets. The quantity of the $\mathrm{Zn}$ and $\mathrm{Cu}$ in the various diets was sufficient in all cases to prevent overt signs of deficiency in the 12-week period of the study and all animals maintained or gained weight over this period. Plasma and liver concentrations of $\mathrm{Zn}$ and $\mathrm{Cu}$ were generally unaffected but fur $\mathrm{Zn}$ was reduced in the casein-fed animals and further reduced in animals given the reduced-salts diets. At the same time, the excretion of $\mathrm{Zn}$ was highest in those given the reduced-salts diets indicating some disturbance of trace element metabolism.

Huff \& Carroll (1980) have suggested that non-protein constituents of the protein preparations may be partially responsible for the induced hypercholesterolaemia of casein-fed animals. The results obtained from the analysis of $\mathrm{Cu}$ and $\mathrm{Zn}$ concentrations in the semi-purified diets indicate that the amounts and dietary $\mathrm{Cu}: \mathrm{Zn}$ values may be important in casein-induced hypercholesterolaemia in rabbits. The mechanism for such an interaction may involve the key enzymes of lipoprotein metabolism, lipoprotein lipase (LPL, $E C$ 3.1.1.34) and lecithin cholesterol acyl transferase (LCAT, EC 2.3.1.43). In Cudeficient rats, it has been suggested (Lau \& Klevay, 1982) that the observed hypercholesterolaemia may be the result of depressed LPL activity, and the decrease in LCAT activity seen in $\mathrm{Cu}$-deficient rats given a casein-containing diet (Harvey \& Allen, 1981) may be due to changes in lipoprotein metabolism. The possible effects of altering the dietary mineral balance on plasma cholesterol levels need to be investigated further.

\section{REFERENCES}

Allen, K. G. D. \& Klevay, L. M. (1978). Atherosclerosis 31, 259-271.

Beynen, A. C. \& van Wanrooy-Stroeken, C. T. M. (1981). Zeitschfirt für Tierphysiologie, Tierernährung und Futtermittelkunde 46, 240-246.

Beynen, A.G. \& West, C. E. (1981). Zeitschrift für Tierphysiologie, Tierernährung und Futtermittelkunde 46, 233-239.

Carroll, K. K. (1971). Atherosclerosis 13, 67-76.

Carroll, K. K. \& Hamilton, R. M. G. (1975). Journal of Food Science 40, 18-23.

Harvey, P. W. \& Allen, K. G. D. (1981). Journal of Nutrition 111, 1855-1858.

Hermus, R. J. J. (1975). Experimental Atherosclerosis in Rabbits on Diets with Milk Fat and Different Proteins. Wageningen; The Netherlands: Centre for Agricultural Publishing and Documentation. 
Huff, M. W. \& Carroll, K. K. (1980). Journal of Nutrition 110, 1676-1686.

Huff, M. W., Hamilton, R. M. G. \& Carroll, K. K. (1977). Atherosclerosis 28, 187-195.

Klevay, L. M. (1973). American Journal of Clinical Nutrition 26, 1060-1068.

Kritchevsky, D. (1979). Journal of the American Oil Chemists Society 56, 135-140.

Lacombe, C. \& Nibbelink, M. (1980). Artery 6, $280-289$.

Lau, B. W. C. \& Klevay, L. M. (1982). Journal of Nutrition 112, 928-933.

Mckenzie, J. M. (1978). American Journal of Clinical Nutrition 31, 470-476.

Mann, G. V. (1961). Clinical Chemistry 7, 275-284.

Meret, S. \& Henkin, R. I. (1971). Clinical Chemistry 17, 369-373.

Roberts, D. C. K. (1981). In Festschrift for F. C. Courtice, pp. 130-138 [D. Garlic, editor]. NSW, Australia: The University of New South Wales, School of Physiology and Pharmacology.

Snedecor, G. W. \& Cochran, W. G. (1968). Statistical Methods, 6th ed., p. 484. Ames: Iowa State University Press. Terpstra, A. H. M. \& Sanchez-Muniz, F. J. (1981). Atherosclerosis 39, 217-227.

Terpstra, A. H. M., Woodward, C. J. H., West, C. E. \& Van Boven, H. G. (1982). British Journal of Nutrition 47, 213-221.

West, C. E., Deuring, K., Schutte, J. B. \& Terpstra, A. H. M. (1982). Journal of Nutrition 112, $1287-1295$.

Wigand, G. (1959). Acta Medica Scandinavica 166, 1-91.

Zlatkis, A. \& Zak, B. (1969). Analytical Biochemistry 29, 143-148. 